\title{
6.20 Методичні прийоми формування у молодших школярів навичок самоконтролю у процесі розв'язування сюжетних задач
}

Самоконтроль в області самоосвіти стає постійним елементом навчальної діяльності і стосується всіх етапів у іiі структурі: учень зіставляє досягнуте 3 очікуваним кінцевим результатом і корегує хід розв’язання проблеми. За цих умов зовнішній контроль трактується ним як "ключ", що підтверджує або спростовує його власні висновки щодо виконаної дії, а з другого - як зовнішня форма самовираження. Мета самоконтролю - запобігання помилкам та їх виправлення. Самоконтроль $є$ засобом активізації свідомості, зміцнення знань, розвитку умінь та навичок учнів. Це метод спонукає школярів до підвищеної відповідальності.

Самоконтроль має дві важливі особливості:

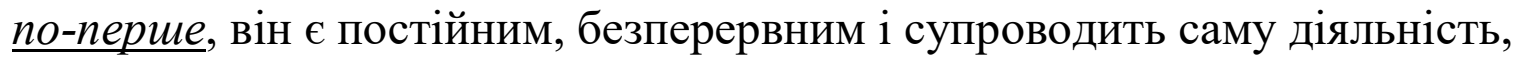
no-дpyze, в його процесі беруть до уваги і приховані огріхи, відомі лише самому учневі, які часто залишаються поза полем зору зовнішнього контролю.

Займаючись розробкою технологічних прийомів розвитку самоконтролю у дітей на уроках в початковій школі, Волявко Д.М. виявила, що учень володіє самоконтролем, якщо уміє:

- свідомо підпорядковувати свої дії заданому комплексу вимог,

- змінювати або зберігати склад своїх дій в умовах діяльності, які змінюються,

- планувати склад дій, визначаючи суб’єктивні труднощі,

- порівнювати дії зі зразком [540].

Потребу розвивати спостережливість, оцінку своїх дій, самокритичність, здатність самому виявити свої помилки і вміти їх позбутися потрібно формувати постійно. Залучення учнів до самоконтролю і самооцінки знань $є$ важливим фактором розвитку у них цих якостей особистості. Перевіряючи й оцінюючи результати своєї роботи, школярі повинні визначити не лише правильність чи неправильність відповіді, засвоєння чи незасвоєння теми, а й те, як одержано результат, яким способом, чи оптимальний він. Але уміння самоконтролю 
нерідко формується недостатньо. Вчителі звертають увагу учнів на потребу перевіряти себе, але як це робити, вчать не завжди. На думку I.В.Тухман, це пов’язано з тим, що недостатньо уваги приділяється розробці загальних методів та прийомів формування самоконтролю у молодших школярів, бо саме в початкових класах починають закладатися способи навчальної роботи, прийоми дій, якими учні будуть користуватися в подальшому навчанні [541, с.20].

На сучасному етапі розвитку шкільної математичної освіти питання про цілі розв’язування сюжетних задач є центральним у методиці початкового курсу математики. Залучення учнів до самоконтролю i самооцінки у процесі розв'язування простих і складених задач $є$ важливим фактором розвитку в них таких якостей особистості як спостережливість, творче мислення, оцінка своїх дій, самокритичність, здатність самому виявляти свої помилки і вміти їх позбутися.

Сформувати вміння самоконтролю в процесі розв'язання сюжетної задачі означає [542, с.27]:

- підпорядкувативласну діяльність поставленій задачі,

- засвоювати правила розв'язання задачі,

- мисленнєво планувати власні дії та наслідки їх виконання у відповідності 3 планом,

- порівнювати заплановані та виконані дії,

- виправляти помилки,

- перевіряти правильність отриманого результату.

Ця методика дозволяс навчити дітей встановлювати взаємозв'язки між елементами умови задачі; врахувати зміни умови і результату в процесі планування; передбачати проміжні і кінцевий результати на певну «глибину»; відшукувати і обирати раціональний варіант розв'язування задачі.

Як зазначає Л.Ілійчук, для успішного використання прийомів формування навичок самоконтролю в учнів молодшого шкільного віку при розв'язуванні сюжетних задач необхідно враховувати наступні педагогічні умови [543, с.159]: - диференційований підхід у використанні самоконтролю; 
- врахування вікових та індивідуальних особливостей учнів;

- систематичність і послідовність використання прийомів у ході навчального процесу;

- різноманітність прийомів самоконтролю;

- сформованість у молодших школярів інтересу до здійснення самоконтролю.

Щоб робота вчителя 3 виховання навичок самоконтролю у процесі розв’язування сюжетних задач виявилася більш ефективною, треба переконати учнів у необхідності самоконтролю і конкретно показати їм як чинити в тому випадку, якщо при перевірці з'ясується, що отримана відповідь не задовольняє умові задачі. Потрібна систематична робота в цьому напрямку, а саме:

1. Треба створити потребу в самоконтролі. Учні повинні частіше зустрічатися 3 реальними умовами, що ставлять їх перед необхідністю самостійно контролювати правильність одержаної відповіді.

2. Зрідка доцільно пропонувати учням такі завдання, неправильність одержаної відповіді яких з'ясується тільки в результаті перевірки.

3. Треба повідомляти учням спосіб перевірки розв'язаної задачі. Пояснювати, що перевіряти треба не тільки остаточну відповідь, а й проміжні результати.

4. Під час аналізу іноді корисно спочатку розглянути не тільки неправильні розв’язки, а й шляхом перевірки довести учням їх неправильність, і лише після цього розглянути правильне рішення.

5. Інколи вчитель навмисно допускає помилки на дошці.

6. У тих темах, в яких це можливо, бажано проводити спостереження та практичні роботи з математики. Самоконтроль при виконанні практичних робіт здійснюється звичайно повторним вимірюванням та обчисленнями (по можливості іншим способом), іноді й безпосереднім вимірюванням шуканої величини.

7. Корисно іноді учням пропонувати самим оцінити свою роботу (контрольну або самостійну). Це підвищує відповідальність учня за її виконання і сприяє вихованню самоконтролю. 
8. Корисно іноді пропонувати учням перевірити i оцінити роботу товариша.

Дуже важливим прийомом навчання молодшого школяра самоконтролю $є$ застосування колективних перевірок у посднанні 3 контролем педагога, тому що в першу чергу школяра потрібно навчити знаходити помилки в іншої людини (контроль). 3 часом учень почне переносити отримані вміння на власну діяльність (самоконтроль). Таким чином, формування контролю йде від контролю за діями інших до самоконтролю. Суть цього прийому полягає в тому, що учні, уважно слухаючи відповідь одного учня, під керівництвом педагога проводять аналіз його відповіді, виявляють допущені помилки і здійснюють колективне їх усунення. Педагог по ходу обговорення розв'язаної задачі задає наступні запитання: «Чи правильний кінцевий результат?», «Чи правильно учень побудував план розв’язання?», «Чи правильний хід розв'язання?»

Фронтальні і взаємні перевірки представляють собою проміжну ланку між контролем педагога і самоконтролем учнів. Застосування їх має ряд переваг при навчанні самоконтролю:

- положення контролерів зобов'язує учнів краще готуватися до занять, щоб мати можливість вказати товаришеві на допущені ним помилки і встановити їх причини;

- колективний аналіз зразка дозволяє більш повно виявити його сигнальні ознаки і більш поглиблено їх засвоїти;

- розбираючи різні способи звірення зі зразком виконуваної роботи, учні відбирають ті з них, які найбільш доцільні в даних умовах. Завдяки цьому досягається велика точність звірення;

- колективний аналіз дозволяє більш повно виявити допущені помилки та встановити їх причини, в ході колективного пошуку виявляються найбільш доцільні способи виправлення помилок і внесення удосконалень у роботу.

Учням доцільно дати завдання, пояснити знайдені помилки того учня, чию роботу вони перевіряли. Це значить, їм доведеться не просто механічно виправляти те, що було неправильно, а обгрунтовувати своє рішення. Вміння не 
тільки бачити помилки, але і виправляти їх і пояснювати їх причини є складовою частиною формування самоконтролю.

Розвиваючи самоконтроль учнів під час розв'язування сюжетних задач, вчитель повинен спрямовувати їх діяльність за допомогою наступних вказівок: «Прочитай...», «Розкажи...», «Поміркуй і скажи...», «Що відомо...?» тощо. Це стимулює самостійність учнів при ознайомленні з текстом задачі та плануванні iiі розв’язання.

У початкових класах доцільно поступово запроваджувати такі прийоми самоконтролю при перевірці правильності розв'язання задачі:

- встановлення відповідності результату й умови, тобто здійснюється перевірка задачі через визначення відповідності між отриманою відповіддю і умовою задачі. Суть цього прийому полягає в тому, що відповідно до опису подій, про які йдеться в задачі, діти використовують необхідні дії над заданими і знайденими числами. Якщо після виконання дій отримують число, яке є в умові, то вважають, що задачу розв'язано правильно.

- розб'язування задачі різними способами веде до розвитку і вміння всебічно аналізувати задачну ситуацію. Суть цього прийому полягає в тому, що якщо задачу можна розв'язати різними способами і при цьому будуть отримані одинакові відповіді, то задача розв'язана правильно. Педагог спонукає учнів до визначення раціонального способу, пояснює, що розв'язання задачі другим способом є не що інше як перевірка вже розв'язаної задачі. Усвідомлення цього $\epsilon$ кроком до пошуку кращого способу, що призводить, у свою чергу, до встановлення нових зв'язків між величинами або використання відомих зв'язків у нових умовах. Вміння знаходити різні способи розв'язання задач означає оволодіння одним із прийомів самоконтролю. Зазвичай порівнюють, який із способів кращий, але необхідно підкреслити, що рішення задачі новим способом одночасно означає перевірку відповіді, отриманої першим способом.

- складання і розб'язування обернених і взаємообернених задач, тобто перетворення прямих задач в обернені і взаємообернені. При перетворенні простої арифметичної задачі в обернену треба шукане задачі взяти за одне 3 
відомих даних нової задачі, а одне з даних задачі вважати шуканим нової задачі. Взаємообернені задачі відрізняються від обернених зміною ключового поняття: наприклад, «більше» стає «меншим». В подібних завданнях правильність розв'язання прямої задачі перевіряється розв'язанням оберненої або взаємооберненої задачі, що дозволяє швидше знайти помилки, виявити причину їх виникнення, на основі зробленого аналізу внести відповідні виправлення. Якщо учні навчаться і звикнуть працювати з оберненими і взаємооберненими задачами, порівнювати умови та їх розв’язки, то поступово вони звикнуть контролювати рішення прямої задачі, а значить у них буде формуватися навичка самоконтролю.

- порівняння відповіді з певним даним числом. У підручниках з математики для початкових класів відповідей до задач не вміщено, але молодших школярів треба навчити звіряти результат 3 тим, який дає вчитель. Самостійне виправлення помилки свідчить про те, що учень зміг проаналізувати умову i запитання задачі, встановити необхідні зв'язки. Залежно від конкретної ситуації і поставленої мети відповіді можна давати як до початку розв'язання задачі, так i після іï розв'язання. Якщо учень зробив помилку, бажано дати йому час поміркувати, щоб він самостійно чи з допомогою вчителя знайшов правильний план розв'язання.

- повторне розв'язання задачі. Ми маємо на увазі повторне розв'язування задачі через деякий час, тобто через кілька днів або тижнів. Цей прийом не належить безпосередньо до творчої роботи, але він відіграє певну роль при формуванні і закріпленні вмінь розв’язувати задачі певного типу. Зустрічаючись із задачею вдруге, учень краще усвідомлює зв'язки між величинами, алгоритм ii розв’язування. Якщо при цьому він розв'яже задачу самостійно, то вона стане вже його “власною”.

- приблизна оцінка шуканих результатів (прикидка). Встановлення можливих меж очікуваної відповіді попереджає недоліки типу описок, пропуску цифр.

Учні повинні знати способи перевірки рішень сюжетних задач i 
застосовувати їх для доведення правильності відповіді. Це теж дуже важливо при формуванні навички самоконтролю, тому що сюжетні задачі складають вагому частину всього матеріалу, що вивчається в початковому курсі математики. Поряд 3 використанням певних прийомів формування самоконтролю, розвиток цієї навички вимагає виконання спеціальних вправ, структурно відмінних від звичайних поширених вправ. Специфіка цих вправ полягає в тому, що учням доводиться не просто виконувати завдання, а так чи інакше контролювати себе. Наведемо приклади деяких з них:

1. Учитель пропонує готове рішення сюжетної задачі, але воно є неправильним. Помилки пропонується виявити учням. Далі учні аналізують помилки, визначають причини їх виникнення, встановлюють, на якому етапі була зроблена помилка і можливість запобігання iï появі.

2. Вчитель приводить неповне розв'язання задачі, а учням пропонує завершити його.

3. Для розв'язування пропонується задача з неповними або надлишковими даними, а учні повинні їх виявити.

4. Розв'язання задачі, пропонованої вчителем, містить принципові прогалини, які пропонується знайти учням.

Ці завдання більше підходять для розвитку уваги дітей, але їх теж необхідно використовувати при підготовці до формування навички самоконтролю, тому що при відсутності уваги не може бути мови ні про самоконтроль, ні про контроль взагалі.

Звичайно у практиці організації самоконтролю при розв'язуванні задач часто виникає потреба забезпечувати учнів еталоном діяльності і очікуваного результату, або хоча б самого результату. Зразок розв'язання задачі, ключ до неї можна запропонувати в індивідуальних картках, в підручнику, на екрані, на дошці.

Відбір методичних засобів формування дій самоконтролю здійснюється на основі врахування як їх специфічного призначення і конкретного психологічного змісту відповідно до етапу діяльності, так і рівня розвитку дітей. Самоконтроль 
можна використовувати до тих знань, умінь та навичок учнів, рівень засвоєння яких вони можуть легко визначити самі [542, с.53].

Самоконтроль учнів не скасовує контролю вчителя і не знижує його ролі, а тільки передує, і тим самим посилює його. Учитель повинен систематично вивчати і аналізувати помилки учнів, звертати увагу на внутрішній зміст, а не на зовнішній, формальний їх бік, повинен виявляти причини їх появи і вживати заходів до попередження помилок. Звичайно це попередження має бути тактовним і не нав’язливим. 